The paperback edition of What It Means To Be 98\% Chimpanzee gives me a chance to rethink and update what I set out to do, which was to relativize the genetic place of humans and apes: not to deny it or challenge it, but simply to place that scientific work in an appropriate cultural and historical context, and to have explored its meaning. I still intend this book to be intensely scientific but also accessible, celebrating the best and abjuring the worst of science. Science is, at its best, self-correcting and relentlessly self-critical.

The issues I discuss remain as vital as ever. Among the new studies published since the book first appeared, some of the material exhibits the same old fallacies: confusing folk ideologies for natural patterns, humanizing apes and ape-ifying humans, and under-theorizing genetic data in an anthropological vacuum. But much of this material, I'm happy to say, is good, normal science. Here are some summaries:

- Svante Pääbo and his colleagues at the Max Planck Institute for Evolutionary Anthropology have found that patterns of gene expression in humans and chimps are quite a bit different in the brain, but less different than in other organs_as we might well expect.

- The biochemist Roy Britten argues that the genetic similarity between humans and chimpanzees is not over $98 \%$, but closer to 
$95 \%$, when you count insertions and deletions of DNA (chapter two). Unfortunately, the problem is not the actual number, but rather the fact that the diversity of genomic mutational processes precludes the calculation of a single value for the genetic difference between human and chimpanzee with any degree of rigor.

- The search for genetic changes that translate directly into the physical distinctions between human and ape is likely futile, but undertaking such a search is tempting nevertheless (chapter eleven). In the quest for what makes us human, differences have been now found between the human and chimpanzee versions of a "brain gene" $(\mathrm{CMAH})$ and a "language gene" (FOXP2). Given that small differences between human and chimpanzee genes will be found everywhere, and that the most basic fact of modern genetics is that phenotypes do not map readily onto genotypes, this kind of theorizing seems conceptually naive, even if high-tech.

- The molecular evidence for the domestication of the dog (chapter four) has now been revised to bring it more in line with the archaeological evidence, and the sequences of Neandertal DNA, while still a technical triumph, show less about the relationships of humans and Neandertals than was initially thought.

- Orangutans now are recognized to possess shared, learned behaviors-as chimpanzees do (chapter eight). How could animals for whom maturity is so delayed and learning is so important to their survival be any different? But it is still not clear how relevant that is to what anthropologists call "culture" in humans. Labeling ape behavior as "culture" simply means you have to find a different word for what humans do.

- The Human Genome Diversity Project (chapter nine) now uses a European collection of cells from indigenous peoples. Examination of these data still shows polymorphism and clinal variation to be the major patterns of human genetic diversity and suggest that geographic separation is the major determinant of the genetic differences among human groups. When researchers asked a new computer program to divide the world's genetic variation into two groups, the result broadly separated Europe, Africa, and Western Asia from the Far East, Oceania, and the New World. When asked to divide the world 
into five, the computer gave results corresponding to the peoples of Africa, Eurasia, East Asia, Oceania, and the Americas; and when asked to divide the world into six, it separated out the Kalash people of Pakistan from those five. On the face of it, this finding would seem to lend no support to popular ideas about race: the Kalash are hardly equivalent to the Africans; and there is certainly nothing racially commonsensical about juxtaposing Eurasia and Africa against East Asia, Oceania, and the Americas. How the New York Times came to represent these newest findings under the headline "Gene Study Identifies 5 Main Human Populations" in their issue of December 20, 2002-along with the ridiculous assertion that they "essentially confirmed the popular conception of race"-is anybody's guess.

- Other population geneticists have recently argued that human races really do exist as natural units, in spite of much of the last half century of research in anthropology and genetics (chapter four). They do so partly by perversely using "population," "race," and "ethnic group" synonymously-although the first term is supposed to be locally, the second globally, and the third culturally designated. If you fail to acknowledge that human groups are fluid, hierarchically organized, and symbolically bounded, it's hard to imagine that the science you do will be of much value. A brief paper by the bioethicists Pamela Sankar and Mildred Cho has effectively responded to and explored the ambiguities inherent in scientific research that uses race as if it were a natural category. The epidemiologists Jay Kaufman and Susan Hall brilliantly dispose of the scientific canard that hypertension in blacks is a genetic disease. And the sociologist Troy Duster has brought to light the financial interests of racialized pharmacogenetics in some of the newest contentious claims.

- A company in Florida will sell you a genetic test to tell you what race you are (as if you don't already know). And then they'll tell you what percentage of each racial ancestry you have. When you're done, be sure to visit the pet psychic. Caveat emptor!

- Judge John Jelderks has been consistently ruling against the Native American tribes in the case of Kennewick Man (chapter ten), but science still hasn't found anything about him that it didn't already 
know, and the whole affair has left a bad taste in many people's mouths. One of the major scientific plaintiffs in the case has even published a paper attacking, of all people, the anthropologist Franz Boas-claiming that Boas's original immigrant study from I9IO, which spawned the field of human adaptability studies, did not really show any change in cranial form, which is fixed genetically and racially. That assertion has the ring of desperation to it (if not obfuscation), and has been quickly rebutted by more mainstream biological anthropology.

- We have heard about the skull of "Peñon Woman"--13,000 years old and looking like the skull of Japanese Ainus, leading a researcher in England to crow, "We're going to say to Native Americans, "Maybe there were some people in the Americas before you, who are not related to you.' " Silly me, I thought we were all related.

- Peñon Woman is also claimed by the scientists who push a preIndian European presence in the New World. But there are still voices of reason amid the chaos: "I personally haven't found it very convincing," said the anthropologist Chris Stringer to a London newspaper. "For a start, there are lots of examples in archaeology where various artifacts from different parts of the world can end up looking similar even though they have different origins ... Most humans in the world at that time were long headed and it doesn't surprise me that Peñon woman at I3,000 years old is also long headed."

- And with a rhetorical flourish, a new study from Morris Goodman's group proclaims (again) that "DNA evidence provides an objective non-anthropocentric view of the place of humans in evolution. We humans appear as only slightly remodeled chimpanzee-like apes." Here "objective" seems to denote merely a blindness to your own intellectual prejudices; for the "slightly remodeled" DNA still produces two species which are adaptively and ecologically rather distinct from each other-incorporating into one of them such trivialities as walking, talking, sweating, sensuality, and civilization (chapter two). That the molecular geneticist can't tell the human from the ape doesn't mean that nobody can; and the sooner they confront that fact, the better.

- All discussions of apes end with conservation. A recent survey 
finds that there are fewer than half as many chimpanzees and gorillas in Gabon today as there were twenty years ago. The principal causes of this decline in numbers are deforestation, hunting, and disease. While I maintain that overstating the humanness of the apes is not a valid justification for our attitudes and actions, it is nevertheless also the case that our natural and cognitive worlds would be immeasurably impoverished by the loss of these species. Broad international action to conserve the apes is desperately needed, in conjunction with efforts to provide for the needs of the local people.

It now seems to me that there are seven well-established patterns of human genetic variation, understanding the meaning of which will be the challenge of the new molecular anthropology:

I. Humans and apes are very similar genetically.

2. They are so similar that different genetic data sets often tell conflicting phylogenetic stories.

3. Compared to apes, humans are depauperate in genetic variation.

4. Human genetic variation is principally polymorphic.

5. Human genetic variation between groups is clinal.

6. All people are genetic subsets of Africans.

7. Genetic variation and behavioral variation do not map easily on to one another in the human species.

I thank Alan Vanneman for correcting my memory about Sherlock Holmes.

Jonathan Marks

Charlotte, North Carolina April 2003 


\section{REFEREN CES}

Britten, R. J. "Divergence between Samples of Chimpanzee and Human DNA Sequences Is $5 \%$, Counting Indels." Proceedings of the National Academy of Sciences, USA 99 (2002): 13633-35.

Connor, S. "Does Skull Prove That the First Americans Came from Europe?" Independent (London), December 4, 2002.

Cooper, R. S., J. S. Kaufman, and R. Ward. "Race and Genomics." New England Journal of Medicine 348 (2003): 1166-70.

Duster, T. "Medicine and People of Color." San Francisco Chronicle, March 17, 2003.

Enard, W., P. Khaitovich, J. Klose, S. Zollner, F. Hessig, P Giavalisco, K. NieseltStreuwe, E. Muchmore, A. Varki, R. Ravid, and S. Pääbo. "Intra- and Interspecific Variation in Primate Gene Expression Patterns. Science 296 (2003): 340-43.

Gravlee, C., H. Berhard, and W. Leonard. "Heredity, Environment, and Cranial Form: A Reanalysis of Boas's Immigrant Data." American Anthropologist 105 (2003): $125-38$.

Hagelberg, E. "Recombination or Mutation Rate Heterogeneity? Implications for Mitochondrial Eve." Trends in Genetics ig (2003): 84-90.

Kaufman, J., and S. Hall, S. "The Slavery Hypertension Hyporhesis: Dissemination and Appeal of a Modern Race Theory." Epidemiology and Society 14 (2003): III-26.

Legon, Jeordan 2002. "Scientist: Oldest American Skull Found." www.cnn.com/ 2002/TECH/science/12/03/oldest.skull/index.html. Retrieved May 7, 2003.

Leonard, J. A., R. K. Wayne, J. Wheeler, R. Valadedez, S. Guillen, and C. Vila. "Ancient DNA Evidence for Old World Origin of New World Dogs." Science 298 (2002): 1613-16.

Pääbo, S. "The Mosaic That Is Our Genome." Nature 42I(2003): 409-II.

Relethford, J. "Absence of Regional Affinities of Neandertal DNA with Living Humans Does Not Reject Multiregional Evolution." American Journal of Physical Anthropology II5 (2001): 95-98.

Risch, N., E. Burchard, E. Ziv, and H. Tang. "Categorization of Humans in Biomedical Research: Genes, Race, and Disease." Genome Biology 3 (2002): 2007.I-I2.

Rosenberg, N. A., J. K. Pritchard, J. L. Weber, H. M. Cann, K. K. Kidd, L. A. Zhivotovsky, and M. W. Feldman. "Genetic Structure of Human Populations." Science, 298 (2002): 218I-85.

Sankar, P., and M. K. Cho. "Toward a New Vocabulary of Human Genetic Diversity." Science 298 (2002): 1337-38.

Sparks, C. S., and R. L. Jantz. "A Reassessment of Human Cranial Plasticity: Boas Revisited." Proceedings of the National Academy of Sciences, USA 99 (2002): I4636-39.

Wade, N. "For Sale: A DNA Test to Measure Racial Mix." The New York Times, October I, 2002. 
Walsh, P. D., et al. "Catastrophic Ape Decline in Western Equatorial Africa." Nature 422 (2003): 6II-I4.

Wildman, D. E., M. Uddin, Guozhen Liu, L. Grossman, and M. Goodman. "Implications of natural selection in shaping $99.4 \%$ nonsynonymous DNA identity between humans and chimpanzees: Enlarging genus Homo." Proceedings of the National Academy of Sciences, USA 100 (2003): 7181-7188. 
This page intentionally left blank 